\title{
ARQUIVO COMO \\ BASE DO TRABALHO JORNALÍSTICO
}

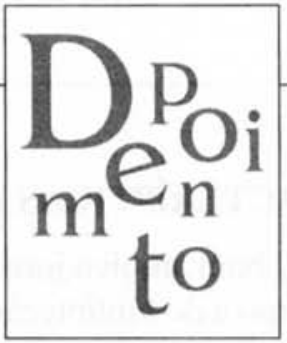

\section{Centros de documentação dão suporte ao trabalho jornalístico, permitindo pautas bem elaboradas e maior precisão das informações}

O jornalista é o historiador do cotidiano. E, como os historiadores, que se reportam ao passado e o reconstroem com base em documentos de todo tipo, o jornalista faz um recorte do presente, destacando, selecionando e descrevendo os acontecimentos.

É lugar comum dizer que a reportagem é a alma do jornalismo. É através dela que o jornalista observa, coleta documentos ou depoimentos para elaborar seus relatos. Mas ela será uma alma rude se ficar apenas no imediatismo dos acontecimentos correntes. Seu conteúdo, graça e encanto, sua ilustração decorrem da habilidade do jornalista em articular a observação direta dos acontecimentos com a informação sistematizada, organizada, que existir a respeito dele, conservada nos departamentos de documentação de seus jornais, revistas, programas de rádio ou televisão.

Prestadores de serviços editoriais por definição, o trabalho dos arquivos geralmente não aparece: ele fornece a retaguarda das boas reportagens e das boas matérias, coleciona as informações cujos seleção e aproveitamento dependem do talento e da inteligência do jornalista.

Os arquivos não são meros depósitos de informações ou de fotografias. Os arquivos jornalísticos têm características próprias, que os distinguem dos demais centros de documentação ou bibliotecas ligados a instituições acadêmicas ou de pesquisa.

A primeira tarefa de um arquivo jornalístico é atender às necessidades editoriais de seus usuários com a rapidez e presteza que a profissão exige. Trabalhando com os mesmos prazos de fechamento e com a urgência que decorre deles, suas pesquisas são sempre para ontem, ao contrário do que ocorre nos demais arquivos e bibliotecas, onde a urgência muitas vezes pode ser medida em dias.

O AUTOR José Carlos Ruy Jornalista, gerente de pesquisa do Departamento de Documentação (Dedoc) da Editora Abril. 


\section{CARACTERÍSTICAS DO ARQUIVO JORNALÍSTICO}

$\mathrm{O}$ bom arquivo jornalístico exige o domínio de técnicas distintas, como a do bibliotecário, a do jornalista e a do técnico em informática. A do bibliotecário, para criar as categorias de classificação e indexação dos livros, recortes de jornal e fotografias. A do jornalista, para quebrar a rigidez e a formalidade do receituário biblioteconômico e fazê-lo aproximar-se da linguagem natural, aquela que é dominada e usada pelos usuários do arquivo. $\mathrm{E}$ a do técnico em informática para, nos locais onde se usem computadores (e que vão se tornando normais, principalmente nos arquivos de maior porte), criar os mecanismos eletrônicos de registro e de pesquisa das informações arquivadas.

Tudo isso é muito simples e informal, mas a simplicidade e a informalidade são qualidades que decorrem de muito trabalho e muita experiência. A coordenação do trabalho de profissionais de perfis tão diferentes é extremamente trabalhosa, muitas vezes conflitiva, e quase sempre sua unificação é muito lenta. Trata-se, é preciso compreender, de traduzir diferentes linguagens e práticas para uma outra, incomum e muito específica, que é a linguagem própria dos centros de documentação jornalísticos, cujas características são agilidade, rapidez, informalidade, transparência, facilidade na busca da informação, simplicidade na operação, uso de linguagem natural (e horror a qualquer forma de linguagem codificada), atualidade e precisão dos conteúdos, organização de pastas temáticas (para recortes de jornal e demais documentos escritos, ou para fotografias) que sejam específicas e não genéricas etc. A simplicidade e informalidade decorrem, também, da disposição e abertura para aprender sempre.

\section{EXPERIÊNCIA PROFISSIONAL}

Minha relação com o trabalho de documentação é antiga. Ela começou antes mesmo de tornar-me jornalista: em meados dos anos 70, no Centro Pastoral Vergueiro - um centro de pesquisa e documentação do movimento popular, ligado à Igreja Católica, que ficava na rua Vergueiro, na vila Brasílio Machado, Ipiranga. Lá descobri a óbvia possibilidade de guardar, de forma organizada, os recortes de jornais mais importantes. Comecei então uma coleção que hoje se transformou numa montanha de papel (apesar de muitas depurações ao longo do tempo) quase inadministrável numa residência. Poucos anos depois, fui convidado para trabalhar no jornal Movimento, semanário da imprensa alternativa que circulou no Brasil entre os anos de 1975 e 81. Lá comecei exatamente no arquivo. Exerci várias outras funções no jornal e me convenci de que 
o arquivo é o melhor caminho para o ingresso em nossa profissão. Após o fechamento do jornal, em 1981, fui contratado pelo Departamento de Documentação - Dedoc, da Editora Abril, onde comecei coordenando a pesquisa de fotografias, passei depois para aquilo que chamamos de "tratamento técnico de fotos" (isto é, sua classificação e indexação) e participei da equipe que iniciou as discussões e o planejamento da informatização do arquivo - isso em 1983/1984, com tecnologia que na época era a mais avançada, hoje virou jurassic park legítimo, e que está em processo de atualização. Em 1987, fui para o Retrato do Brasil, coleção de fascículos sobre a História recente do Brasil, coordenada pelo jornalista Raimundo Pereira, mas que, infelizmente, faliu. Andei um pouco pelo mercado, fui depois para a Editora Globo, onde coordenei a mudança para São Paulo e reorganização aqui do Centro de Documentação - Cedoc, praticamente sem nenhuma tecnologia eletrônica. No Cedoc coordenei o início da organização lógica dos materiais, definição das pastas de texto e fotografias, organização da biblioteca de acordo com as normas usuais baseadas na Classificação Decimal Universal ${ }^{1}$ (a organização anterior fora criada no próprio arquivo, uma atitude temerária pois gera uma enorme quantidade de problemas de arquivamento e localização dos livros que o uso da CDU elimina), criação de um dicionário de indexação cruzando as referências e as classificações e definição de um fluxo de materiais documentais entre as redações e o arquivo, esclarecendo responsabilidades e o papel de cada profissional. Hoje, tenho notícia de que a Globo também está informatizando seu arquivo, com ganhos enormes para os jornalistas e, claro, para os documentaristas. Voltei, depois, para o Dedoc da Editora Abril, onde me envolvi em projetos como a revisão do arquivo fotográfico, a modernização tecnológica do arquivo, além de pesquisa, muita pesquisa.

É um trabalho para quem gosta. Ele une, penso, qualidades do jornalista, do historiador e do documentarista. Quem prefere as luzes da ribalta certamente se sentirá infeliz nesta função - e sairá dela rapidamente, procurando um lugar nas redações. Os melhores levarão consigo o aprendizado do arquivo, do contato com a informação organizada e sistematizada. Serão então jornalistas de excelente qualidade. São aqueles que, antes de sair para uma reportagem, para uma entrevista, para uma sessão de fotos, procuram saber o que já existe a respeito de suas pautas.

1. Ver sobre o assunto: TÁLAMO, Maria de Fátima G. M., LARA, Marilda L. G. de, KOBASHI, Nair Y. Vamos perseguir a informação. Comunicação \& Educação. São Paulo: CCA-ECA-USP/Moderna, n.4, set./dez. 1995. p.52-57. 
Poderão conhecer as fotos que existem, qual o enquadramento, como foi a produção etc. e fazer, assim, fotos melhores. Vão descobrir os gostos, idiossincrasias, hábitos, o passado e a história de seus entrevistados ou dos assuntos que lhes cabe investigar. Conseguirão localizar e compreender os fatos de sua pauta em uma série mais ampla que a mera cotidianeidade. Farão então textos instigantes, inteligentes. É para isso que os departamentos de documentação existem.

Resumo: $\mathrm{O}$ autor trata da especificidade e características dos departamentos de documentação de jornais, revistas, rádio e televisāo. Destaca a necessidade de estes arquivos estarem adequados para atenderem com rapidez, precisăo e objetividade aos seus usuários, garantindo facilidade na busca da informação e simplicidade na operação dos acervos. Relata sua experiência na organização e coordenação de arquivos em empresas jornalisticas como a Globo e a Abril.

Palavras-chave: arquivo jornalístico, documentação, pauta, Abril, Globo
Abstract: The author deals with the specificity and with the characteristics of the newspaper, magazine, radio and television documentation departments. The article emphasizes the need for these files to be adequate to serve their user quickly, accurately and objectively, insuring ease in the search for information and simplicity to operate the collections. The author reports on his experience at organizing and coordinating files at journalistic companies such as Globo and Abril.

Key words: journalistic file, documentation, agenda, Abril, Globo 